\title{
Usporedba dva komercijalna fiksativa pri upotrebi u rutinskim histološkim analizama
}

1 Ljerka Armano

2 Romana Gračan

1 KBC Sestre milosrdnice, Zagreb, Hrvatska

2 Sveučilište u Zagrebu, Prirodoslovno-matematički fakultet, Biološki odsjek, Zagreb, Hrvatska

\section{Sažetak}

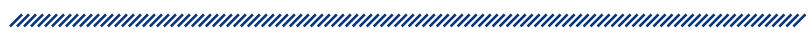

Fiksiranje tkiva važan je korak u histološkoj obradi tkiva za izradu trajnih mikroskopskih preparata. Svrha fiksacije je očuvanje stanica i međustaničnih struktura kako bi što više nalikovali živom materijalu. $U$ ovom istraživanju analizirali smo morfološke značajke unutrašnjih organa potočne pastrve (Salmo trutta L.) fiksirani s dva različita fiksativa. 10\% neutralni puferirani formaldehid (PNF) koji daje kvalitetne histološke uzorke, ali je toksičan i kancerogen te zamjenskog fiksativa FineFix-a (FF) smanjene toksičnosti baziranog na etanolu. Kako bi usporedili učinak dva istraživana fiksativa, tkiva su nakon fiksacije uklopljena u paraplast, izrezana i obojena rutinskomn histološkom hemalaun eozinskom (HE) tehnikomte histokemijskom metodom bojenja perjodne kiseline i Schiffovog reagensa te alcijanskog modrila. Uzorci tkiva probavnog, dišnog i cirkulacijskog sustava potočne pastrvepokazalisu da je PNF i dalje najbolji izbor pri standardnoj fiksaciji za histološke i histokemijske analize. Kao najveća razlika između dva upotrebljena fiksativa ističe se kvaliteta fiksacije vezivnog tkiva u proučavanim organima, koja je bolja u tkivima fiksiranim s PNF, u usporedbi s FF, dok se FF istaknuo kao bolji fiksativ u HE bojenju preparata probavnog sustava. Ukoliko će se i dalje upotrebljavati PNF, određena osjetljiva tkiva poput probavnih organa mogu zahtijevati modificiranje standardnih postupaka bojenja, a naročito HE metode, kako bi se osigurao bolji afinitet tkiva za boju, a time i bolje prepoznavanje morfoloških struktura u tkivu, dok se potraga za zamjenskim, jednako kvalitetnim, fiksativom bez formalina i dalje nastavlja.

Ključne riječi: fiksativi, formalin, formaldehid, FineFIX, histologija

Datum primitka: 29.11.2019.

Datum prihvaćanja: 15.01.2020.

https://doi.org/10.24141/1/6/1/1

Adresa za dopisivanje:

Ljerka Armano

Trnsko 33b, 10020 Zagreb, Hrvatska

E-mail: ljerka.armano@gmail.com

T: +385993195129 


\section{Uvod}

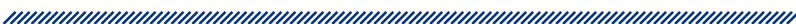

Fiksiranje tkiva prvi je i najvažniji korak u izradi trajnih histoloških preparata koji omogućuju proučavanje tkiva i promatranje mikroskopskih struktura svjetlosnim mikroskopom. Budući da nije uvijek moguće održati strukturu tkiva što sličnijom onom u živom organizmu, od presudne je važnosti dobar izbor fiksativa jer o njemu ovisi kvaliteta histoloških preparata. Kemijski fiksativi su otopine koje u potpunosti ulaze u tkivo te stabiliziraju ili križno povezuju tkivne bjelančevine čime osim stabilizacije staničnih struktura dodatno sprečavaju truljenje i autolizu stanica i time štite histologe od moguće infekcije mikroorganizmima iz tkiva, te tkivu daju tvrdoću kako bi se olakšalo rezanje i bojenje i smanjilo oštećenje tkiva tijekom daljnjih postupaka ${ }^{1}$.

Zlatni standard fiksacije u rutinskim dijagnostičkim postupcima je $4 \%$ ili $10 \%$ puferirani neutralni formaldehid (formalin). Aktivan sastojak neutralnog formalina je formaldehid koji prilikom fiksacije ne koagulira proteine već s njima reagira tvoreći metilenske mostove ${ }^{2}$. Široko rasprostranjen, formalin se desetljećima svakodnevno koristi u medicini, veterini, stomatologiji i biologiji, a titulu zlatnog standarda stekao je nizom svojih pozitivnih karakteristika: brzo prodire u tkiva, morfološke karakteristike tkiva dobro su očuvane, dozvoljava korištenje većine histokemijskih metoda, prihvatljive je cijene i omogućava dugotrajno skladištenje².

Zbog stoljetne primjene često se ne pridaje dovoljno velika važnost njegovim toksičnim svojstvima ${ }^{3}$ iako je neosporno njegovo štetno djelovanje. Dokazan štetan utjecaj formaldehida na ljude te izazivanje karcinoma nazofarinksa, leukemije ${ }^{4,5}$ kromosomske promjene kod zdravstvenih radnika u laboratorijima za patologiju ${ }^{6}$ trebali bi biti jak poticaj za preispitivanje postojećeg znanja o nezamjenjivosti formaldehida, te preispitivanja moguće upotrebe alternativnih sredstava ${ }^{7}$. U posljednjih dvadesetak godina predlagani su brojni pripravci kao zamjena formalinu ${ }^{8-13}$, ali ni jedna od predloženih otopina nije dobila na važnosti u široj uporabi.

Zbog njegove smanjene toksičnosti, u ovom istraživanju kao alternativa formaldehidu korišten je FineFIX fiksativ na bazi alkohola. On djeluje tako da uklanja slobodnu vodu iz tkiva pri čemu dolazi do taloženja i koaguliranja proteina. Proizvođači FineFIX-a kao glavne karakteristike ističu dobro očuvanje tkivnih antigena i stanične morfologije, smanjenje lize eritrocita, primjenu u većini histoloških, histokemijskih, imunohistokemijskih i citoloških reakcija, te lako skladištenje i odlaganje ${ }^{14}$.

Kako bi se ocijenila kvaliteta i usporedila ova dva fiksativa 1) standardno korišteni neutralni puferirani formaldehid koji daje kvalitetne histološke uzorke, ali je potencijalno toksičan te 2 ) zamjenski fiksativ (FineFix) na bazi etanola smanjene toksičnosti, pripremljeni su trajni histološki preparati glavnih unutarnjih organa potočne pastrve (Salmo trutta) fiksirani s dva navedena fiksativa, te se uspoređivala očuvanost glavnih morfoloških obilježja tkiva. Osim toga, ocjenjivala se i kvaliteta obojenosti tkiva pri upotrebi rutinske histološke hemalaun eozinske tehnike te rutinske histokemijske kombinirane metode bojenja (perjodne kiseline i Schiffovog reagensa te alcijanskog modrila). Aplikativna vrijednost rada ogleda se u prijedlogu uporabe fiksativa koji pokazuje bolju sačuvanost stanične morfologije i bolju obojenost tkiva pri izradi standardnih histoloških rezova pomoću parafinske tehnike.

\section{Materijali i metode}

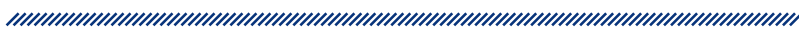

\section{Priprema fiksativa}

Korišteni su $10 \%$ puferirani neutralni formaldehid (PNF) i FineFIX (FF). Radne otopine oba fiksativa pripremljene su svježe prema preporuci proizvođača, a čuvanje, priprema, skladištenje kao i fiksiranje tkiva vršeno je u istovjetnim uvjetima i istim protokolom.

\section{Tkiva}

Uzorci potočne pastrve koji su korišteni u ovom istraživanju potječu iz ribogojilišta Gacka. Za histološku analizu pripremljeni su uzorci 6 životinja za fiksaciju FFom i 5 životinja za fiksaciju PNF-om. Svježi uzorci tkiva unutarnjih organa pastrve (srce, želudac, crijeva, jetra, gušterača, škrge) veličine $0,5 \mathrm{~cm}^{3}$ fiksirani su tijekom 24 sata pri identičnim uvjetima (temperatura, svjetlost, volumen fiksativa, trajanje fiksacije). Ukupno je izrađeno 79 trajnih histoloških preparata koji su pregledani svjetlosnim mikroskopom, a u radu su prikazani samo najreprezentativniji primjerci. 
Nakon fiksacije tkivo se uklapa u paraplast (parafin) kako bi tkiva dobila čvrstoću i bila pogodna za rezanje. Postupku uklapanja tkiva u paraplast prethode dva pripremna postupka: dehidriranje i prosvjetljavanje. Iz fiksiranih komadića tkiva uklanja se voda uzastopnim prenošenjem uzoraka kroz rastuće koncentracije etanola (obično od $70 \%$ do $100 \%$ etanola). Nakon toga etanol se zamjenjuje kloroformom koji omogućuje uklop i prožimanje tkiva tekućim paraplastom na temperaturu od 58 do $60^{\circ} \mathrm{C}^{15}$. Pod utjecajem topline kloroform ispari i svi prostori u tkivu ispune se paraplastom. Mali blokovi tkiva hlade se na sobnoj temperaturi pri čemu se stvrdnu $i$ zatim režu pomoću mikrotoma na rezove debljine $6 \mu \mathrm{m}$. Rezovi se zatim prenesu na predmetna stakalca i suše 24 sata na sobnoj temperaturi. Prije postupka bojenja iz tkiva se uklanja paraplast i vrši se rehidracija tkiva u padajućim nizovima alkohola i vodi jer su histološke boje uglavnom vodene i tek tada su tkiva spremna za bojenje.

\section{Rutinske histološke i histokemijske metode bojenja}

Kako bi bezbojne prereze tkiva mogli promatrati svjetlosnim mikroskopom potrebno ih je obojiti. Bojenje se izvodi mješavinom boja koje manje ili više selektivno prikazuju dijelove tkiva. Korištene su dvije metode bojenja: 1) hemalaun-eozin (HE) i 2) perjodna kiselina i Schiffov reagens sa alcijanskim modrilom (PAS/AB). Temeljem rutinske HE tehnike procjenjivao se vizualni izgled preparata i morfološke karakteristike tkiva (ukupna morfologija tkiva, koherentnost i povezanost tkiva) i kvaliteta bojenja (uniformnost, stanične, izvanstanične i citoplazmatske komponente). Rutinskom histokemijskom PAS/AB metodom ocjenjivala se obojenost $i$ izgled samih stanica (skvrčivanje ili nabubrenost stanica i jezgri) te citoplazmatska organizacija u stanicama i struktura jezgre.

\section{Svjetlosna mikroskopija}

Histološki preparati obojeni HE i PAS/AB metodom analizirani su svjetlosnim mikroskopom (Nikon Eclipse E600). Mikroskopske snimke trajnih histoloških preparata snimljene su digitalnom kamerom (Nikon DXM 1200) i obrađene ZEN2 lite programom za obradu slika slika (Carl Zeiss Microscopy GmbH). Za preparate obojene HE koristilo se povećanje 100x i 200x, a za preparate obojene PAS/AB metodom 200x i 400x.

\section{REZULTATI}

Od ukupno 6 unutarnjih organa potočne pastrve fiksiranih u dva različita fiksativa izrađeno je 79 trajnih histoloških preparata koji su uspoređivani analizom digitalnih histoloških slika. U usporedbi su korišteni i ocjenjivani najkvalitetniji fiksirani uzorci. Na manjim povećanjima oba fiksativa su fiksirala tkiva dovoljno dobro da su svi organi histološki prepoznatljivi i adekvatni za histološke analize struktura unutar tkiva. Obje metode bojenja su dale primjerene kontraste, obojile očekivane strukture i omogućile morfološku preglednost tkiva. Kao najveća razlika između dva upotrijebljena fiksativa istaknula se kvaliteta fiksacije vezivnog tkiva u proučavanim organima, koja je bolja u tkivima fiksiranim s PNF, u usporedbi s FF. S druge strane, FF je bolje fiksirao krvne stanice u krvnim žilama jer je krv bila puno više prisutna u nekim organima, pogotovo $u$ jetri koja je prožeta velikim krvnim žilama.

\section{Fiksacija pomoću $10 \%$ neutralnog puferiranog formaldehida (PNF)}

Pri pregledu svjetlosnim mikroskopom obje metode bojenja HE i PAS/AB prikazuju primjerena morfološka obilježja za srčani mišić. Vidljive su naslage srčanih stanica te vezivno tkivo koje ih povezuje. Integritet tkiva nije u potpunosti očuvan što se očituje stvaranjem pukotina između pojedinih stanica.

Pokrovni i žljezdani epitel želučanog tkiva je sačuvan, vezivno tkivo je cjelovito kao i dobro vidljivi mišići ali se uočava nedovoljna istaknutost hemalauna tj. bazofilnih struktura što je nabolje vidljivo na žlijezdama u sluznici koje sadržavaju i eozinofilne i bazofilne stanice.

Preparat crijeva prikazuje primjerena morfološka obilježja a pokrovni jednoslojni cilindrični epitel se jasno uočava kao i vrčaste žljezdane stanice. Vezivno i mišićno tkivo je dobro očuvano i cjelovito. Kao i kod želučanog tkiva zapaža se nedovoljna istaknutost hemalauna.

Vizualnim pregledom preparata jetre uočavaju se jetreni režnjići, jetreni hepatociti su pravilne veličine i spojeni u zrakasto poredane tračke između kojih se nalaze jetrene sinusoide. Obojenost tkiva je primjerena, uočavaju se ljubičasta zrnca glikogena u hepatocitima kao i plavo obojene jezgre krvnih stanica u krvnim žilama.

Vizualnim pregledom HE preparata fiksiranih s PNF vidljiva je primjerena struktura i organizacija guštera- 
če. Endokrini dijelovi gušterače, Langerhansovi otočići, obojeni su svjetlije u odnosu na egzokrine acinuse.

Preparat škrga prikazuje primjerena morfološka obilježja koja omogućavaju njegovu trenutnu prepoznatljivost: pokrovni epitel škržnih lamela je dobro očuvan kao i vezivno tkivo ispod njega a dobro je vidljiv i škržni skelet sa očuvanom hrskavicom. I ovdje dolazi do izražaja nedovoljna istaknutost hemalauna.

\section{Fiksacija FineFix-om (FF)}

Pri fiksaciji FF-om srčani mišić prikazuje smanjenu kvalitetu fiksiranja pa je endomizij još više raspucan, mišićni slojevi gube koherentnost a jezgre unutar stanica su skvrčene.

Pokrovni epitel želučanog tkiva je dobro vidljiv ali je struktura žljezdanog tkiva lošija kao i kvaliteta vezivnog tkiva a samim time i povezanost među slojevima. Analizom kvalitete boje ovog preparata primijeti se dominantnost hemalauna što je u suprotnosti s tkivima fiksiranima PNF-om.

Na preparatu crijeva dobro je vidljiv pokrovni epitel kao i žljezdane stanice iako su lošije očuvane. Kao glavni problem ističe se lošije fiksirano vezivno tkivo te mišićni sloj koji pokazuje jaču skvrčenost u odnosu na tkivo fiksirano PNF-om. Na preparatu dominira ljubičasto obojenje jer je tkivo bolje reagiralo s hemalaunom.

Tkivo jetre fiksirano s FF-om pokazuje lošiju morfološku sliku tkiva. Hepatociti su smanjene veličine i međusobno odvojeni što narušava vizualizaciju strukture jetrenog režnjića. Pozitivna strana ovog fiksativa očituje se u boljij očuvanosti krvnih stanica u krvnim žilama i sinusoidama.

Osnovna morfološka struktura tkiva gušterače fiksiranog s FF-om je prepoznatljiva ali se ponovno pokazuje lošije strukturirano vezivno tkivo, nešto lošije sačuvano masno tkivo kao i stanice egzokrinog dijela gušterače koje su nešto manje, tj skvrčene.

Na preparatu škrga ističe se dobra obojenost i hemalauna i eozina što omogućuje brzu i jednostavnu identifikaciju pojedinih struktura u tkivu. Struktura tkiva je nešto lošija prvenstveno zbog lošije kvalitete vezivnog tkiva.

Slika 1 prikazuje usporedbu tkiva unutrašnjih organa potočne pastrve bojena HE metodom fiksirane $10 \%$ puferiranim neutralnim formaldehidom te FineFIX-om, dok na slici 2 vidimo usporedbu tkiva unutrašnjih organa fiksirana s oba fikasativa i bojena PAS/AB metodom. lako su oba fiksativa u većini promatranih kriterija podjednako dobri, mala prednost ipak se daje PNF-u. Značajna prednost FF daje se na preparatima probavnog sustava jer bolje boji HE (hemalaun eozinsko) bojenje od tkiva fiksiranih u formaldehidu. Komparacija morfoloških osobina i reakcija na pojedine rutinske boje (HE, $\mathrm{PAS} / \mathrm{AB}$ ) pri histološkoj analizi preparata unutarnih organa potočne pastrve fiksiranih $\mathrm{s}$ dva fiksativa prikazana je u tablici 1.

\section{Rasprava}

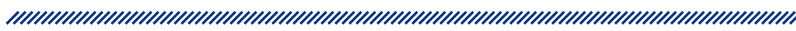

Istraživanja koja se odnose na korištenje različitih fiksativa u histološkim preparatima kod nas su rijetka iako pretraživana literatura daje opsežne rezultate. Najveći broj radova je iz područja kliničke patologije u medicini. S obzirom da su u ovom radu korištene samo dvije rutinske tehnike bojenja i da u tkivima nisu prepoznate histopatološke promjene, u daljnjem ispitivanju ovih fiksativa moraju se uzeti u obzir i te varijable, te se shodno tome istraživanje može proširiti.

Fiksiranje tkiva vrlo je važan korak u histološkoj obradi preparata. Dobra fiksacija je izazov u radu budući da se kod svih metoda javlja skupljanje tkiva, bubrenje i otvrdnjavanje. Uz to fiksacija i odabir fiksativa bitno utječu na tkivnu obradu a naročito rezanje i bojenje ${ }^{1}$. Najosjetljivijim organima smatraju se jetra, gušterača i probavni trakt, zbog prisutnosti probavnih enzima u tim organima koji sami počnu razgrađivati tkivo ukoliko fiksativ ne djeluje dovoljno brzo ${ }^{16}$.

Formaldehid je mala molekula koja postoji u obliku plina, a u laboratorij dolazi kao $37 \%$ vodena otopina. Za očuvanje morfologije tkiva $\mathrm{i}$ ispitivanje histokemijskim $\mathrm{i}$ imunohistokemijskim metodama najčešće se koristi kao $10 \%$ vodena otopina ( $4 \%$ formaldehid) ili kao puferirana otopina ( $10 \%$ neutralni puferirani formaldehid) ${ }^{17,18}$. Neutralni puferirani formaldehid karakterizira brzo prodiranje u tkivo i brza fiksacija ${ }^{19}$. U posljednjih nekoliko godina predlagani su brojni pripravci kao alternativa formali$n u^{8-13}$, ali ni jedna od predloženih otopina nije dobila na važnosti u široj uporabi. Zbog duge primjene (>100 god.) i tituli zlatnog standarda često se ne pridaje dovoljno velika važnost toksičnim svojstvima formaldehida ${ }^{3}$. Prilikom svakodnevnog izlaganja formalinu mora se uzeti u obzir i njegovo kancerogeno djelovanje $\mathrm{e}^{12,19,20}$. 

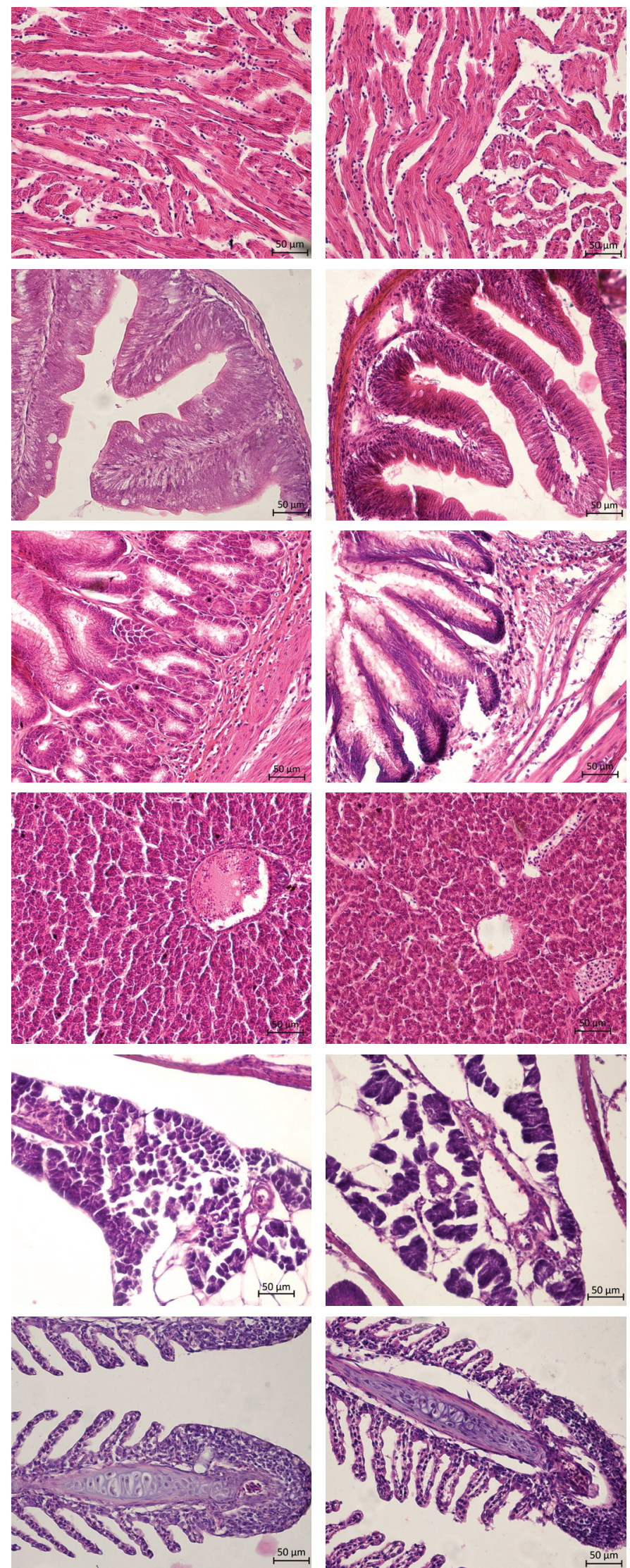

Slika 1.

Histološki prikaz unutrašnjih organa potočne pastrve Salmo trutta fiksiranih s $10 \%$ puferiranim neutralnim

formaldehidom (lijevi stupac: $a, b, c, d, e, f)$ ili Finefix fiksativom (desni stupac: $g, h, i, j, k, l$ ) (a, g - jetra; b, h - tanko crijevo; c, i -želudac; $d, j$ - jetra; e, k - gušterača; f, l - škrge). HE, 200X 

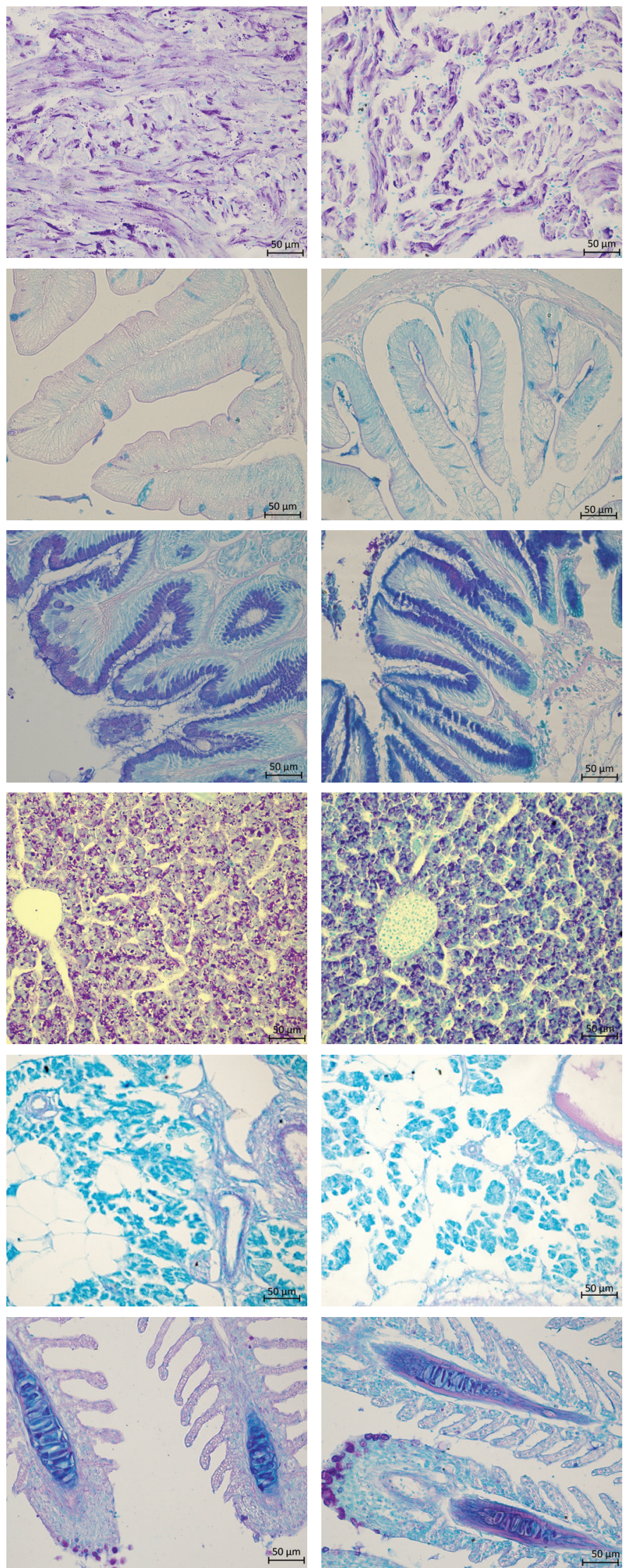

Slika 2.

Histološki prikaz unutrašnjih organa potočne pastrve Salmo trutta fiksiranih s $10 \%$ puferiranim neutralnim formaldehidom (lijevi stupac: a,b,c,d,e,f) ili Finefix fiksativom (desni stupac: $g, h, i, j, k, l$ ) 
Tablica 1. Komparacija morfoloških osobina i reakcija na pojedine rutinske boje (HE, PAS/AB) pri histološkoj analizi preparata unutarnih organa potočne pastrve fiksiranih s dva fiksativa: PNF (10\% neutralni puferirani formaldehid) i FF (FineFix). Opisne ocjene: 1-3, pri čemu je 1 najmanja vrijednost, a 3 najbolja ocjena tkiva. HE - hemalaun eozin, PAS/AB - perjodna kiselina i Schiffov reagens u kombinaciji s alcijanskim modrilom

\begin{tabular}{|c|c|c|c|c|c|c|c|c|c|c|c|c|}
\hline & \multicolumn{2}{|c|}{ srce } & \multicolumn{2}{|c|}{ želudac } & \multicolumn{2}{|c|}{ crijevo } & \multicolumn{2}{|c|}{ jetra } & \multicolumn{2}{|c|}{ gušterača } & \multicolumn{2}{|c|}{ škrge } \\
\hline & PNF & FF & PNF & FF & PNF & $\mathrm{FF}$ & PNF & FF & PNF & $\mathrm{FF}$ & PNF & FF \\
\hline raspoznavanje histoloških tkiva & 3 & 3 & 3 & 3 & 3 & 3 & 3 & 3 & 3 & 3 & 3 & 3 \\
\hline povezanost pojedinih tkiva & - & - & 3 & 2 & 3 & 2 & 3 & 2 & 2 & 1 & 3 & 2 \\
\hline očuvanost krvnih stanica & 2 & 3 & - & - & - & - & 2 & 3 & 1 & 2 & - & - \\
\hline očuvanost masnog tkiva & - & - & - & - & - & - & - & - & 2 & 1 & - & - \\
\hline očuvanost žljezdanih tkiva & - & - & 3 & 3 & 3 & 2 & - & - & 2 & 1 & - & - \\
\hline očuvanost vezivnog tkiva & 3 & 2 & 3 & 2 & 3 & 2 & 3 & 2 & 2 & 1 & 3 & 2 \\
\hline izgled samih stanica & 3 & 2 & 3 & 2 & 3 & 2 & 3 & 2 & 2 & 1 & 2 & 3 \\
\hline obojenost HE & 2 & 2 & 2 & 3 & 2 & 3 & 3 & 3 & 2 & 2 & 1 & 3 \\
\hline obojenost PAS/AB & 2 & 2 & 3 & 2 & 3 & 2 & 3 & 3 & 2 & 2 & 2 & 2 \\
\hline ukupna ocjena & 3 & 2 & 3 & 2 & 3 & 2 & 3 & 3 & 2 & 1 & 3 & 3 \\
\hline
\end{tabular}

Godine 1987. američka Agencija za zaštitu okoliša (eng. Environmental Protection Agency) klasificirala je formaldehid kao vjerojatni kancerogen za ljude u uvjetima neobično visoke ili dugotrajne izloženosti ${ }^{21}$. IARC (eng. International Agency for Research Cancer) ukazuje na povezanost formaldehida s karcinomom nazofarinksa i leukemije kod ljudi, ${ }^{4,5}$. Ovi rezultati potvrđeni su i u izvješću za 2012. od strane iste agencije ${ }^{22}$. Podaci o utjecaju formaldehida na ljude trebali bi biti jak poticaj za preispitivanje "formalinske dogme" u svrhu upotrebe alternativnih sredstava ${ }^{7}$. U novije vrijeme otkrivene su kromosomske promjene kod zdravstvenih radnika koje su povezane s primjenom formalina u laboratorijima za patologiju ${ }^{6}$. Zajednica patologa uglavnom zanemaruje ovakve informacije smatrajući uporabu formaldehida sigurnom ukoliko se pri manipulaciji poštuju sigurnosne mjere opreza ${ }^{23}$.

Sredstva na bazi alkohola kao što su npr. Carnoyev i Methacarnojev fiksativ djeluju tako da denaturiraju proteine ${ }^{24}$, što rezultira koagulacijom proteina i skupljanjem tkiva. Opsežni su radovi o molekularnim fiksativima kao što su FineFIX, F-Solv, RCL2 ${ }^{25,26}$ i Paxgene ${ }^{27}$ koji navode negativne značajke fiksativa poput sporije brzine fiksacije te lošije očuvanosti eritrocita,. Prema Howat i Wilson ${ }^{28}$ FineFIX uzrokuje i degranulaciju mastocita. Slične rezultate dobili su Singhal i sur. ${ }^{29}$ iz kojih se vidi da su fiksativi na bazi alkohola dali dobre rezultate kada se radi o bojenju preparata, dok je samo tkivo bilo više skvrčeno u odnosu na fiksative bazirane na formalinu. S druge strane FineFIX se pokazao kao dobar izbor za proteomske analize jer dobro sačuva integritet DNA i RNA ${ }^{3}$. Rezultati ovog istraživanja su u skladu s rezultatima navedenih autora jer se i u ovom istraživanju FineFIX pokazao kao lošiji fiksativ što se tiče očuvanosti masnog tkiva, žljezdanog tkiva, vezivnog tkiva, povezanosti pojedinih tkiva, kao i izgledu samih stanica.

Loša kvaliteta bojenja u slučaju tkiva fiksiranog u $10 \%$ neutralnom puferiranom formaldehidu može biti posljedica loše fiksacije što dovodi do nepotpune dehidracije jer zaostala voda neće biti zamijenjena parafinom, čineći tkivo podložnim degradaciji ${ }^{30}$. Također, loša kvaliteta bojenja u slučaju tkiva fiksiranih fiksativima na bazi alkohola može biti posljedica činjenice da je tkivo koje je previše fiksirano manje propusno za boje što rezultira lošijom kvalitetom bojenja ${ }^{5}$. S obzirom da izbor fiksativa utječe na bojenje neki autori su modificirali protokole bojenja. Cooper i sur. ${ }^{16}$ držali su uzorke duže u kiselom alkoholu kako bi se bolje obojile strukture koje imaju manje izražene bazofilne karakteristike. Isti protokol bilo bi dobro primijeniti na uzorke probavnog sustava ovog istraživanja koji su bili fiksirani PNF-om jer nisu pokazali adekvatnu obojanost hemalaun eozinom. 
Neutralni puferirani formalin pokazao se superiornijim od FineFIX-a s obzirom na makroskopski izgled tkiva, morfološke strukture tkiva kao i histološke i histokemijske analize ${ }^{26}$. Kao glavni nedostatak FF ističe se raskidanost vezivnog tkiva koja dovodi do pojave artefakata, lošija morfološka očuvanost stanica te lošiji afinitet za PAS/AB bojanje ${ }^{26,31}$. Razvojem znanosti i novih otkrića za pretpostaviti je da će se u budućnosti razviti novi tipovi fiksativa koji će postati zlatni standard i promijeniti formalinsku dogmu.

\section{Zaključak}

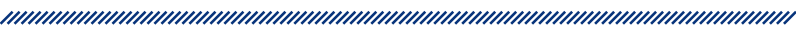

$\mathrm{Na}$ temelju rezultata histoloških i histokemijskih metoda bojanja možemo zaključiti da je 10\% PNF i dalje najbolji izbor pri standardnoj fiksaciji za histološke i histokemijske analize. Određena osjetljiva tkiva poput probavnih organa zahtijevaju modificiranje standardnih postupaka bojenja a naročito HE metode kako bi se osigurao bolji afinitet tkiva za boju.

\section{Reference}

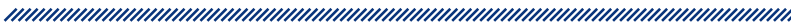

1. Bancroft J.D., Gamble M. (2008): Theory and practice of histological techniques. Churchill Livingstone Elsevier, London.

2. Junqueira L.C., Carneiro J., Kelley R.O. (1995): Osnove histologije. Školska knjiga, Zagreb.

3. Muthuselvi S. (2017): Evaluation and comparative analysis of newer compound fixatives. Disertation. Department of Pathology Tirunelveli Medical College, Tirunelveli.

4. Cogliano V.J., Grosse Y., Baan R.A., Straif K. et al. (2005): Meeting report: summary of IARC monographs on formaldehyde, 2-butoxyethanol, and 1-tert-butoxy-2-propanol. Environ Health Perspect. 113:1205-8.

5. Baan R., Grosse Y., Straif K., Secretan B. et al. (2009): WHO International agency for research on cancer monograph working group: A review of human carcinogens. Part F: Chemical agents and related occupations. Lancet Oncol. 10:1143-4.

6. Santovito A., Schilirò T., Castellano S., Cervella P. et al. (2011): Combined analysis of chromosomal aberrations and glutathione S-transferase M1 and T1 polymorphisms in pathologists occupationally exposed to formaldehyde. Arch Toxicol. 85:1295-302.

7. Zanini C., Gerbaudo E., Ercole E., Vendramin A. et al. (2012): Evaluation of two commercial and three home-made fixatives for the substitution of formalin: a formaldehyde-free laboratory is possible. Environ Health. 4:11-59.

8. Olert J., Wiedorn K.H., Goldmann T., Kuhl H. et al. (2001): HOPE fixation: a novel fixing method and paraffin-embedding technique for human soft tissues. Pathol. Res. Pract. 197:823-6.

9. Gillespie J.W., Best C.J., Bichsel V.E., Cole K.A. et al. (2002): Evaluation of non-formalin tissue fixation for molecular profiling studies. Am J Pathol. 160:449-57.

10. Vincek V., Nassiri M., Nadji M., Morales A.R. (2003): A tissue fixative that protects macromolecules (DNA, RNA and protein) and histomorphology in clinical samples. Lab Invest. 83:1427-35.

11. Delfour C., Roger P., Bret C., Berthe M.L. et al. (2006): RCL2, a new fixative, preserves morphology and nucleic acid integrity in paraffin embedded breast carcinoma and microdissected breast tumor cells. J Mol Diagn. 8:157-69..

12. Stanta G., Mucelli S.P., Petrera F., Bonin S. et al. (2006): A novel fixative improves opportunities of nucleic acids and proteomic analysis in human archive's tissues. Diagn Mol Pathol. 15:115-23.

13. Mueller C., Edmiston K.H., Carpenter C., Gaffney E. et al. (2011): One-step preservation of phosphoproteins and tissue morphology at room temperature for diagnostic and research specimens. PLoS One. 6:e23780.

14. FineFIX (Formaline Substitute) (2015): Handbook of protocols for: fixation \& imunohistochemistry. MM029-005FineFIX-Operator manual. Preuzeto sa https://abacusdx. 
com/wp-content/uploads/2015/05/Milestone-FineFIXBrochure.pdf. (pristupljeno 23.7.2019.)

15. Cvitas Jurković E. (2015): Prednost korištenja novih reagenasa u patohistološkoj dijagnostici. Specijalistički rad. Farmaceutsko-biokemijski fakultet, Zagreb.

16. Cooper J.E., Budgeon L.R., Foutz C.A., van Rossum D. et al. (2018): Comparative analysis of fixation and embedding techniques for optimized histological preparation of zebrafish. Comp Biochem Physiol C Toxicol Pharmacol. 208:34-46.

17. Fox C.H., Johnson F.B., Whiting J., Roller P.P. (1985): Formaldehyde fixation. J Histochem Cytochem. 33:845-53.

18. Masuda N., Ohnishi T., Kawamoto S., Monden M. et al. (1999): Analysis of chemical modification of RNA from formalinfixed samples and optimization of molecular biology applications for such samples. Nucleic Acids Res. 27:4436-43.

19. Kiernan J.A. (2008): Histological and histochemical methods. Theory and practice.

20. Scion Publishing, Bloxham.

21. Costa S., Coelho P., Costa C., Silva S. et al. (2008): Genotoxic damage in pathology anatomy laboratory workers exposed to formaldehyde. Toxicology. 252:40-8.

22. U.S. Environmental Protection Agency (EPA). Office of air and radiation (1989): Report to congress on indoor air quality. Assessment and Control of Indoor Air Pollution. 2:2-27.

23. IARC (2012): Chemichal agents and related occupations. IARC Monographs on the evaluation of carcinogenic risks to humans. International Agency for Research of Cancer, Lyon.
24. Buesa R.J. (2008): Histology without formalin?. Ann Diagn Pathol. 12:387-96.

25. Baker J.R. (1958): Fixation in cytochemistry and electron microscopy. J Histochem Cytochem. 6:303-8.

26. Bostwick D.G. (1994): Establishment of the formalin-free surgical pathology laboratory. Utility of an alcohol-based fixative. Arch Pathol Lab Med. 118:298-302.

27. Moelans C.B., ter Hoeve N., van Ginkel J.W., ten Kate F.J. et al. (2011): Formaldehyde substitute fixatives. Analysis of macroscopy, morphologic analysis, and immunohistochemical analysis. Am J Clin Pathol. 136:548-56.

28. Kap M., Smedts F., Oosterhuis W., Winther R. et al. (2011): Histological assessment of PAXgene tissue fixation and stabilization reagents. PLoS One. 6:e27704.

29. Howat J.W., Wilson B. A. (2014): Tissue fixation and the effect of molecular fixatives on downstream staining procedures. Methods. 70:12-9.

30. Singhal P., Singh N.N., Sreedhar G., Banerjee S. et al. (2016): Evaluation of histomorphometric changes in tissue architecture in relation to alteration in fixation protocol - An in vitro study. J Clin Diagn Res. 10:28-32.

31. Hewitt S.M., Lewis F.A., Cao Y., Conrad R.C. et al. (2008): Tissue handling and specimen preparationin surgical pathology: issues concerning the recovery of nucleic acids from formalin-fixed paraffin-embedded tissue. Arch Pathol Lab Med. 132:1929-35.

32. Aydin I., Yorukoglu K., Cingoz S., Agilkaya S. (2013): The effect of the alternative solutions to formaldehyde and xylene on tissue processing. Indian J Pathol Microbiol. 56:221-30. 


\section{COMPARISON OF TWO COMMERCIAL FIXATIVES FOR APPLICATION IN ROUTINE HISTOLOGY ANALYSIS}

\author{
1 Ljerka Armano \\ 2 Romana Gračan \\ 1 KBC Sestre milosrdnice, Zagreb, Croatia \\ 2 Univesity of Zagreb, Faculty of Science, Department of \\ Biology, Zagreb, Croatia
}

\section{Summary}

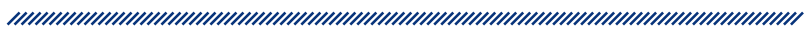

Tissue fixation is a very important step when preparing tissue for permanent histological samples. The purpose of fixation is to preserve cells and extracellular structures to resemble living material as much as possible. In this study we analysed morphological characteristics of major internal organs of the brown trout (Salmo trutta L.), after fixation with two different fixatives: $10 \%$ neutral buffered formaldehyde (NBF), which produces highquality histological samples, but is toxic and carcinogen and FineFix (FF) ethanol-based substitution for NBF with reduced toxicity. For proper comparison ofstudied fixatives, tissue samples were fixed, embedded in paraplast, sectioned and stained with routine hemalaun eosin (HE) technique and histochemical staining method for Periodic Acid - Schiff's reaction combined with alcian blue. Based on the analysis of the tissue samples from the digestive, respiratory and circulatory system of the brown trout our results show that NBF is a better choice of fixation for histological and histochemical analyses. The major difference between the two fixatives is the quality of connective tissue in the studied organs, which is better in NBF fixed tissues compared to FF, while FF stands out as better when staining digestive system organs with HE. Therefore, if using NBF, certain sensitive tissues, such as the digestive organs, may require modification of standard staining procedures, and in particular the HE method, to provide better tissue affinity for color and thus better recognition of tissue morphological structures, while search for adequate non-formaline fixative still continues.

Keywords: fixative, formalin, formaldehyde, FineFIX, histology 